\title{
PENGEMBANGAN MEDIA ISPRING SUITE 8 DENGAN MODEL THINK PADA MATA KULIAH GENETIKA
}

Ismi Nurul Qomariyah ${ }^{1 *}$, Mistianah ${ }^{1}$

${ }^{1}$ IKIP Budi Utomo Malang Jl. Citandui No. 46 Malang, Jawa Timur

* corresponding author | email : isminurul88@gmail.com mahasiswa Pendidikan Biologi. Jenis penelitian ini adalah Research and Development. Pengembangan media pembelajaran menggunakan metode Research and Development (R \& D) dengan model 4 D (Define, Design, Develop, dan Dessiminate). Penelitian ini dimulai dari tahap define yaitu mengidentifikasi konsep-konsep material yang harus terkandung dalam media. Mendesain lebih lanjut model pembelajaran Think berbasis media pembelajaran I Spring Suite 8. Setelah media dirancang dan dibuat maka dilakukan tahap pengembangan yaitu validasi produk oleh ahli dan uji coba produk pada proses perkuliahan. Hasil penelitian menunjukkan bahwa validitas ahli materi dalam kriteria valid dengan persentase 88 persen, hasil validitas ahli media dalam kriteria valid dengan persentase media pembelajaran sebesar 89 persen. Dari uji kelayakan diperoleh hasil uji kelayakan. Disimpulkan bahwa media termasuk dalam kategori sangat baik.

\section{Kata Kunci : pengembangan, ispring suite 8, genetika}

This study aims to develop I Spring suite 8 learning media based Think learning model for Biology Education college students. The type of this research was Research and Development. The development of learning media uses the Research and Development (R \& D) method with the 4 D model (Define, Design, Develop, and Dessiminate). This research starts from the define stage that was identificatethe material concepts that must be contained in media. Furthermoredesign the I Spring suite 8 learning media based Think learning model. After media has been designed and created, the development stage was carried out, namely product validation by experts and product testing in the lecture process. The results showed that the validity of the material experts was in valid criteria with the percentage of 88 percent, the results of validity by media experts were in valid criteria with the percentage of learning media as much as 89 percent.From the feasibility test, it was concluded that the media is included in the category very good.

Keywords : development, ispring suite 8, genetics

Pendidikan di era digital merupakan pendidikan yang harus mengintegrasikan teknologi informasi dan komunikasi ke dalam seluruh mata pelajaran. Pengaruh perkembangan teknologi yang pesat semakin terasa di berbagai aspek kehidupan, tidak terkecuali pada dunia pendidikan. Pendidikan di era digital memungkinkan mahasiswa mendapatkan pengetahuan yang berlimpah 
ruah, cepat serta mudah. Oleh karena itu, maka dosen dan mahasiswa di abad 21 harus mampu berkomunikasi dan beradaptasi mengikuti perkembangan jaman dan perkembangan teknologi. Pada proses pembelajaran, seorang pengajar atau dosen harus dapat menguasai dan memilih alat pembelajaran yang tepat untuk digunakan pada proses pembelajaran. Hal tersebut bertujuan agar materi pembelajaran yang diberikan akan diterima dengan baik oleh mahasiswa, sehingga proses pembelajaran akan berlangsung secara efektif. Salah satu alat pembelajaran yang mengajarkan mahasiswa dapat mandiri adalah modul pembelajaran. Oleh karena itu, modul perlu dirancang dan dipersiapkan dengan memperhatikan perkembangan teknologi dan kebutuhan mahasiswa di era digital.

Hamalik dalam Nurseto (2011) memaparkan bahwa pemanfaatan media dalam proses pembelajaran dapat membangkitkan keinginan dan minat baru, meningkatkan motivasi dan rangsangan kegiatan belajar, dan bahkan berpengaruh secara psikologis kepada mahasiswa. iSpring suite 8 merupakan salah satu softwaremedia pembelajaran yang penggunaannya sangat mudah dengan hasil yang memuaskan. Pengembangan media iSpring suite 8 dengan model pembelajaran Thinkfokusky diharapkan dapat mengembangkan motivasi dan minat belajar mahasiswa pada mata kuliah Genetika.

Dalyono (2009) menyatakan bahwa motivasi merupakan salah satu faktor internal yang memiliki peran penting dalam keberhasilan pembelajaran karena merupakan kekuatan mental yang mendorong terjadinya proses belajar. Mahasiswa memerlukan motivasi agar mereka bersemangat tanpa ada motivasi, maka tujuan pembelajaran yang telah ditetapkan tidak akan tercapai. Secara ringkas, motivasi belajar adalah dorongan internal dan eksternal pada mahasiswa yang sedang belajar untuk mengadakan perubahan tingkah laku, pada umumnya dengan beberapa indikator atau unsur yang mendukung.

Berdasarkan hasil observasi di kelas, terlihat motivasi dan pemahaman konsep mahasiswa Program Studi Pendidikan Biologi IKIP Budi Utomo Malang pada Matakuliah Genetika masih relatif rendah. Hal tersebut terlihat dari beberapa hal. Pertama, mahasiswa belajar ketika akan menghadapi ujian semester saja. Kedua, mahasiswa kadang mencontek pada saat Ujian Semester karena mereka tidak percaya diri dengan kemampuan yang telah dimiliki atau kurang mempersiapkan diri untuk menghadapi ujian semester. Hal ini berartimotivasi belajar mahasiswa masih "kurang". Di samping itu, diketahui mahasiswa cenderung kurang memperhatikan dosen pada saat proses pembelajaran, sehingga pemahaman konsep mahasiswa terhadap materi rendah.

Kurangnya motivasi dan pemahaman konsep mahasiswa tersebut salah satunya disebabkan karena materi pada Matakuliah Genetika bersifat sulit dan abstrak. Mahasiswa masih kesulitan dalam memahami materi genetika karena memang bersifat abstrak. Genetika adalah suatu ilmu cabang Biologi yang mempelajari tentang materi genetik dan kerjanya. Sehingga diperlukan suatu upaya untuk mempermudah pemahaman konsep mahasiswa, salah satunya dengan menggunakan media iSpring suite 8 dengan model pembelajaran Think. Dalam media iSpring suite 8 dapat dimasukkan konten video dan suara sehingga mempermudah mahasiswa dalam memahami materi genetika. Berdasarkan penjelasan di atas, maka tujuan dari penelitian ini adalah menghasilkan produk berupa media iSpring suite 8 dengan model pembelajaran Think pada mata kuliah genetika.

iSpring Suite 8 merupakan salah satu tool yang mengubah file presentasi menjadi bentuk flash dan bentuk SCORM/ AICC, yaitu bentuk yang biasa digunakan dalam pembelajaran dengan elearning LMS (Learning management System). iSpring Suite 8 secara mudah dapat diintegrasikan dalam Microsoft power point sehingga penggunaannya tidak membutuhkan keahlian yang rumit. Beberapa fitur Ispring Suite 8 adalah (1) Ispring Suite 8 bekerja sebagai add-ins PowerPoint, untuk menjadikan file PowerPoint lebih menarik dan interaktif berbasis Flash dan dapat dibuka di hampir setiap komputer atau platform. (2) Dikembangkan untuk mendukung e-learning. Ispring Suite 8 dapat menyisipkan berbagai bentuk media, sehingga media pembelajaran yang dihasilkan akan lebih menarik, diantaranya adalah dapat merekam dan sinkronisasi video presenter, menambahkan Flash dan video YouTube, mengimpor atau merekam audio, menambahkan informasi pembuat presentasi dan logo perusahaan, serta membuat navigasi dan desain yang unik. (3) Mudah didistribusikan 
dalam format flash, yang dapat digunakan dimanapun dan dioptimalkan untuk web. (4) Membuat kuis dengan berbagai jenis pertanyaan/soal (Hernawati, 2010).

iSpring Suite 8 merupakan perangkat untuk membuat media pembelajaran yang bersifat presentasi yang dapat digunakan dalam proses pembelajaran yang memuat aspek media pada audio, visual, audio visual, dan beragam jenis evaluasi yang sudah disediakan. Selain itu, iSpring Suite 8 dapat mengkonversi file powerpoint menjadi bentuk flash yang aktraktif sehingga user dapat menggunakannya, baik secara langsung maupun dioptimalkan untuk pembelajaran dalam bentuk elearning, sehingga siswa dapat berinteraksi langsung terhadap materi yang disampaikan ditambah dengan materi-materi pokok dalam power point (Pritakinanthi, 2017).

Model pembelajaran THINK adalah model pembelajaran yang dikembangkan oleh Kelly untuk melatih kemampuan metakognisi siswa dan untuk membantu siswa berkomunikasi selama memecahkan masalah secara kooperatif. Model pembelajaran ini disebut THINK (Talk atau Bicara, How atau Bagaimana, Identify atau Identifikasi, Notice atau Pemberitahuan, dan Keep atau Menjaga). Langkah pembelajarannya yatu: (1) Siswa mendiskusikan masalah yang dimulai dengan "TTalk". Mereka menggambarkan situasi yang terjadi dalam masalah dan men-jelaskan apa yang ditanyakan dan mengiden-tifikasi informasi penting. (2) Selanjutnya, fokus pada "H-How", bagaimana masalah dapat diselesaikan. Selain bertukar pikiran (ide) untuk memecahkan masalah siswa juga diminta untuk memutuskan dan menjelaskan mengapa mereka berpikir untuk menyelesai-kan masalah. (3) Selanjutnya, tahapan "Identify", yaitu mengidentifikasi strategi atau rencana penyelesaian masalah. Aspek penting di sini adalah bahwa siswa diminta untuk berpikir dan mengevaluasi kelebihan dan kekurangan dari rencana atau strategi yang digunakan.(4) Untuk memahami pema-haman siswa, mereka diminta untuk "N-Notice", bagaimana strategi yang digunakan membantu menyelesaikan masalah. (5) Akhirnya, siswa diminta untuk memeriksa apa yang dilakukan melalui "K-Keep Think-ing" tentang masalah dan menentukan apakah pemecahan masalah itu bermakna. Menurut Kelly, berdasarkan hasil peneli-tiannya, penggunaan panduan THINK adalah salah satu latihan metakognisi untuk memandu interaksi di antara siswa dalam menyelesaikan masalah (La Misu dkk, 2019).

\section{METODE}

Penelitian ini adalah penelitian pengembangan atau yang lebih dikenal dengan Research and Development ( $R$ \& D). Penelitian ini bertujuan untuk menghasilkan sebuah produk baru yangbermanfaat dalam proses pembelajaran. Pengembangan Media i Spring suite 8 menggunakan metode Research and Development (R\&D) dengan model 4 D (Define, Design, Develop, dan Dessiminate).

Penelitian ini dimulai dari tahap define yaitu dengan mengidentifikasi konsep-konsep materi yang harus dimuat dalam media. Selanjutnya pada tahap design dilakukan perancangan dan pembuatanmedia. Setelah media selesai dirancang dan dibuat, dilakukan tahap develop yaitu validasi produk oleh pakar dan uji coba produk dalam proses perkuliahan. Berdasarkan hasil tahap develop ini, baru bisa dinyatakan produk valid dan praktis serta bisa dilanjutkan ke tahap dessiminate (penyebarluasan).

Data didapatkan melalui media angket. Jenis data yang dihasilkan adalah data kualitatif dan data kuantitatif. Data kualitatif adalah saran ataupun kritik yang dituliskan oleh validator.Data kuantitatif adalah data yang berasal dari angket yang berisi rating scale. Angket ini berisi kolomkolom yang menunjukkan tingkatannya. Jawaban angket dengan menggunakan angka Likert dengan empat kategori pilihan yaitu angka 4 berarti sangat baik, angka 3 berarti baik, angka 2 berarti kurang baik, dan angka 1 berarti tidak baik.

Analisis data kualitatif mengacu pada hasil saran, kritik atau komentar dari validator.Saran atau komentar yang diberikan oleh validator tersebut dapat ditindaklanjuti atau dapat tidak ditindaklanjuti. Tindak lanjut ini tergantung dari dapat dilakukan atau tidaknya perbaikan tersebut. Analisis data kuantitatif dilakukan berdasarkan hasil angket penilaian instrumen dengan skala Likert 
dan dianalisis dengan analisis persentase. Penilaian dilakukan dengan menggunakan rumus berikut.

$$
P=\frac{\sum x i}{\sum x j} \times 100 \%
$$

Keterangan:

P : Taraf Persentase

$\sum x i$ : jumlah skor penilaian

$\sum x j$ : skor maksimal

Berdasarkan hasil nilai persentase tersebut, selanjutnya dibandingkan dengan jenjang kualifikasi penilaian pada Tabel 1 untuk menentukan kriteria dari instrumen dan keperluan revisi produk.

Tabel 1. Jenjang Kualifikasi Penilaian Instrumen

\begin{tabular}{ccccc}
\hline $\begin{array}{c}\text { Taraf Persentase } \\
(\%)\end{array}$ & Nilai Huruf & Keterangan Huruf & Kriteria Validitas & Keterangan \\
\hline $84-100$ & A & Sangat Baik & Valid & Tidak Revisi \\
$62-<84$ & B & Baik & Cukup Valid & Revisi \\
$41-<61$ & C & Kurang Baik & Kurang Valid & Revisi \\
$<41$ & D & Tidak Baik & Tidak Valid & Revisi \\
\hline
\end{tabular}

Dimodifikasi dari Setiawan (2012)

\section{HASIL DAN PEMBAHASAN}

Hasil dari penelitian ini adalah produk media iSpring suite 8 dengan model pembelajaran dan deskripsi data hasil validasi modul pembelajaran dengan hasil sebagai berikut.

\section{Tahap DEFINE}

Pada tahap definepeneliti mengidentifikasi konsep-konsep materi yang harus dimuat dalam media. Adapun konsep materi yang dimuat adalah konsep pengertian genetika, pengantar genetika, peranan genetika, materi genetik, kromosom, DNA dan RNA, syarat materi genetik, percobaan materi genetik dan dogma sentral.

\section{Tahap DESIGN}

Pada tahap design dilakukan perancangan dan penyusunan media iSpring suite 8 dengan model pembelajaran Think. Media berisi pendahuluan, Materi, dan gambar-gambar yang berhubungan dengan materi.Media didesain sesuai dengan model pembelajaran Think.Selan itu, pada media juga dilengkapi latihan soal yang bertujuan untuk melihat kemampuan mahasiswa setelah mempelajari materi Genetika. Media pembelajaran di desain agar mampu mempermudah mahasiswa dalam proses pembelajaran.

\section{Tahap DEVELOP}

Setelah media iSpring suite 8 dengan model pembelajaran Thinkselesai dirancang dan disusun, dilakukan tahap developyaitu validasi produk oleh ahli media dan ahli materi. Hasil validasi produk media iSpring suite 8 dengan model pembelajaran Think dapat dilihat pada Tabel 2 . Berdasarkan hasil validasi modul oleh ahli materi pada Tabel 2, diketahui bahwa hasil validasi oleh ahli materi diperoleh $89 \%$, maka modul parasitologi berbasis Fokusky sangat layak digunakan dalam pembelajaran. Adapun saran yang diberikan oleh ahli materi yaitu perlu ditambahkan beberapa ilustrasi gambar terkait materi Parasitologi. 
Tabel 2. Hasil Validasi Modul oleh Ahli Materi

\begin{tabular}{|c|c|c|c|}
\hline No & Kriteria Kelayakan & $\%$ & Kriteria \\
\hline 1 & Kesesuaian dengan SK & 90 & Sangat Layak \\
\hline 2 & Kesesuaian dengan KD & 80 & Layak \\
\hline 3 & Kebenaran konsep & 90 & Sangat Layak \\
\hline 4 & Kesesuaian tingkat perkembangan mahasiswa & 100 & Sangat Layak \\
\hline 5 & Mendukung pemahaman terhadap materi & 100 & Sangat Layak \\
\hline 6 & Kejelasan info dan mudah dipahami mahasiswa & 80 & Layak \\
\hline 7 & Kesesuaian dengan kaedah bahasa Indonesia & 80 & Layak \\
\hline 8 & Kesesuaian penggunaan istilah & 90 & Sangat Layak \\
\hline 9 & Bahasa jelas dan singkat & 90 & Sangat Layak \\
\hline 10 & Kemenarikan ilustrasi dan gambar & 90 & Sangat Layak \\
\hline & $\begin{array}{ll}\text { Rata-rata } \\
\end{array}$ & 88 & Sangat Layak \\
\hline
\end{tabular}

Tabel 3. Hasil Validasi Modul oleh Ahli Media

\begin{tabular}{|c|c|c|c|}
\hline No & Kriteria Kelayakan & $\%$ & Kriteria \\
\hline \multirow{3}{*}{$A$} & Kelayakan Isi & & \\
\hline & 1. Kebermaknaan media & 88 & Sangat Layak \\
\hline & 2. Penulisan naskah & 90 & Sangat Layak \\
\hline B & Tata bahasa & 85 & Sangat Layak \\
\hline $\mathrm{C}$ & Tampilan media & 90 & Sangat Layak \\
\hline & Rata-rata & 89 & Sangat Layak \\
\hline
\end{tabular}

Berdasarkan hasil validasi modul oleh ahli media pada Tabel 3, diketahui bahwa hasil validasi oleh ahli media diperoleh rata-rata $89 \%$, maka media iSpring suite 8 dengan model pembelajaran Thinksangat layak digunakan dalam pembelajaran. Adapun saran yang diberikan oleh validator ahli media adalah pengurangan warna pada cover media. Dari hasil validasi ahli materi diperoleh ratarata $88 \%$ sehingga media iSpring suite 8 dengan model pembelajaran Think sangat valid.

\section{KESIMPULAN DAN SARAN}

\section{Kesimpulan}

Hasil penelitian menunjukkan bahwa validitas oleh ahli materi berada pada kriteria sangat valid dengan persentase modul parasitologi sebesar $88 \%$, hasil validitas oleh ahli media berada pada kriteria sangat valid-dengan persentase media pembelajaran sebe-sar $89 \%$. Kelebihan media ini adalah langsung terhubung dengan media mobile sehingga mudah digunakan dan tidak membuat bosan.

\section{Saran}

Media pembelajaran yang bisa digunakan sangat banyak dan beragam, jad sebagai seorang guru atau pengajar disarankan untuk menggunakan dan memanfaatkan berbagai macam media pembelajaran sehingga bisa memudahkan dalam proses pembelajaran dan meningkatkan hasl belajar siswa.

\section{DAFTAR RUJUKAN}

Dalyono, M. 2009. Psikologi Pendidikan. Jakarta: Rineka Cipta.

Hernawati, K. 2010. Modul Pelatihan iSpring Presenter. Disampaikan dalam Kegiatan PPM dengan judul: Pelatihan Pembuatan Media Pembelajaran Interaktif dengan Perangkat Lunak Ispring 
Presenter Bagi Guru Sekolah Menengah pada Tanggal 23 Juli 2010 di Laboratorium Komputer Jurdik Matematika FMIPA Universitas Negeri Yogya.

La Misu, Lukito, A., Hasnawati\& Utu Rahim, U. 2019. Profile of Metacogni-tion of Mathematics Education Students in Understanding the Concept of Inte-gral in Category Classifying and Summarizing. International Journal of In-struction, 12(3), 481-496.

Nurseto, T. 2011. MEMBUAT MEDIA PEMBELAJARAN YANG MENARIK. Jurnal Ekonomi \& Pendidikan. $8(1)$

Pritakinanthi, AS. 2017. Pengembangan Media Pembelajaran Menggunakan iSpring untuk Meningkatkan Hasil Belajar Mata Pelajaran Bahasa Inggris Kelas VIII SMP Negeri 37 Semarang. Skripsi tidak diterbitkan. Jurusan Kurikulum Dan Teknologi Pendidikan, Fakultas IImu Pendidikan, Universitas Negeri Semarang. 